\title{
Tekstlingvistikkens problemer
}

\author{
Ib Ulbæk
}

Artiklen tager afsæt i Simon Borchmanns grundlagsdiskussion af tekstlingvistikken i Tekster og sproghandlinger (2010). Han mener, at tekstlingvistikkens hidtidige praksis har været for abstrakt og for lidt pragmatisk. Konkret afviser han bidragene fra kohæsionsteorien for tekster og makrostrukturteorien. Selv om Borchmanns kritik accepteres et stykke af vejen, så er synspunktet i nærværende artikel, at begge teorier har noget at bidrage med i forståelsen af tekster. Samtidig gøres det klart, at bidragene ikke er den hele sandhed for hvordan kohærens skabes i tekster, idet der er egenskaber ved dem, som ikke indfanges af dem, men $\mathrm{fx}$ af min egen pipelineteori.

Der kan ikke herske tvivl om, at problemet med at forstå, hvad en tekst egentlig er, ikke er nogen let opgave. Hvis man tror andet, kan man blot læse Simon Borchmanns tankevækkende artikel, Tekster og sproghandlinger: introduktion til et tema og en problematik (Borchmann 2010). Jeg vil i det følgende tage afsæt i denne artikels påvisninger af afsporinger inden for tekstlingvistikken og Borchmanns forsøg på at bringe den tilbage på rette spor. Dette gør jeg for at tænke videre ad de samme baner som Borchmann, men også for at søge at korrigere nogle af fremstillingerne.

Borchmanns kritik retter sig primært mod tekstlingvistiske begreber som makrostruktur og kohæsion og teorierne bag. Forhistorien findes i Saussure og strukturalismen med dennes fokusering på sprogsystem og manglende forståelse for sprogbrugens egenart. Dette retter tekstlingvistikken fra 1970erne og frem op på, men ifølge Borchmann på forkert grundlag. Trods det, at tidligere teorier inddrog ytringen i sprogbeskrivelsen, valgte man den forkerte basale enhed, nemlig udsagnet (Borchmann 2010:5) og det forkerte teoretiske fundament, det formalistiske/generative (Borchmann 2010:7). Dog er det nok mest den tidlige van Dijk, karakteristikken gælder for, idet en anden af tekstlingvistikkens fædre, Michael Halliday, har sit eget 
funktionalistiske standpunkt. Den samlende opfattelse bliver i stedet kaldt sprogsystematisk tekstlingvistik: at der er konstitutive regler for tekster af sprogsystematisk art.

Fra dette udgangspunkt retter sig en mere detaljeret kritik af to af de begrebsdannelser, som stammer fra netop disse to ophavsmænd ${ }^{1}$ : makrostrukturteorien og kohæsionsteorien. Her foretager Borchmann en overraskende samtænkning, idet han gør de to teorier til en samlet beskrivelse for tekster. Den ene redegørende for teksters globale sammenhæng, den anden for den lokale sammenhæng: "I det følgende beskrives to termer der er særligt centrale i forhold til hhv. det globale og det lokale tekstkriterium: makrostruktur og kohoesion" (Borchmann 2010:9). Hvorfor det er overraskende vender jeg tilbage til senere.

Hans kritik af de to teorier for kohærens og kohæsion er følgende:

1) At grundlaget er problematisk (her erklærer Borchmann sig enig med Harders kritik (1979), som han gennemgår, Borchmann 2010:13ff.). Den formalistiske tilgang har sætningen som grænse og den synes svær at overvinde i tekstlingvistikken. Den formalistiske tilgang har som sagt udsagnet og ikke ytringen som udgangspunkt. Det giver så det problem, at selv om man kobler pragmatiske overvejelser på, så er udgangspunktet for den makrostrukturelle rekonstruktion tænkt forud for pragmatisk processering (Borchmann 2010:16).

2) At makrostrukturreglernes og kohæsionsanalysens anvendelse er uklar, hvis man ikke har en forud givet viden om konteksten for teksten, herunder viden om de mulige beskrivelser, referenter kan have, for at man kan samordne (og udskille) forskellige udtryk som koreferentielle. Makrostrukturteorien kan således ikke være en model for tekstforståelse.

3) Som konsekvens: at man dømmer nogle tekster ude af tekstbegrebet og andre inde, som tydeligvis er konstruerede og kunstige.

Som overordnet alternativ foreslår Borchmann (i samklang med Harder) den fundamentale præmis, at tekster bruges interaktionelt og skrives og læses med formål, og det er af det formål, man skal læse teksten vellykkethed, herunder hvordan informationsstrukturen i ytringen udnyttes (Borchmann 2010:18ff.). 


\section{Ib Ulbak}

Når jeg i det følgende forsøger at drage nogle af Borchmanns konklusioner i tvivl, så er det ikke, fordi jeg er uenig i hans overordnede tilgang. Den er jeg ganske enig i. Men jeg mener faktisk, at nogle af de indsigter, som både makrostrukturteorien og kohæsionsanalysen kommer med, er forenelig hermed og derfor stadig har relevans for en nutidig tekstlingvistik. Og jeg accepterer termen tekstlingvistik, jf. at undertitlen på min bog Sproglig tekstanalyse (Ulbæk 2005) er "introduktion til pragmatisk tekstlingvistik". Det skyldes, at jeg mener, tekstlingvistikken har et langt mere begrænset sigte end fx betegnelsen tekstpragmatik ville signalere. Forskellen mellem os skyldes måske, at jeg er mere tilbøjelig til at acceptere pointer fra formalistisk hold (ikke nødvendigvis Chomskys mange programmer for en grammatik, men formel og logisk semantik, som kan have en plads i sprogbeskrivelsen. Det er økumenisk indrømmer jeg; men ordet er ikke altid et eufemistisk synonym for inkonsekvent og inkonsistent sammentænkning). Mere om det senere...

\section{Det tekstkonstituerende}

Tekstlingvistikken blev sat i verden for at løse det problem, som tekster udgør. For så vidt som det har været almen tænkning, at grammatik og semantik alene beskæftiger sig med sprogligt materiale, som ligger inden for sætningsgrænsen, og for så vidt, at pragmatikken i sin begyndelse har gjort det samme, blot forankrede enkeltsætningerne i kontekst, så har der manglet en redegørelse for, hvad der sker, når sætninger (ytringer) samvirker og udgør den helhed, som teksten er. Det er den redegørelse, tekstlingvistikken har ønsket at give, og som har været dens raison d'etre. Udgangspunktet har været den simple iagttagelse, at tekster ikke er tilfældigt sammenbragte sætninger, og at disse ikke tilfældigt sammensatte sætninger står i en ikke tilfældig orden.

Til at forklare ovennævnte to forhold ved tekster har tekstlingvistikken introduceret begrebet kohærens: at der i tekster, som har de to egenskaber, hersker kohærens. Det, man altså siger, er, at tekster er kohærente eller sammenhængende (vi kan godt tillade os denne pædagogiske synonymisering). Så længe begrebet kohærens ikke er udfoldet, så har det ikke meget forklarende karakter, men kun beskrivende. Det siger blot, at det er et essentielt træk ved tekster, at de er sammenhængende.

Et tidligt forsøg på at give en redegørelse for kohærens var at angive, at der skulle være referentielt sammenfald mellem diskurselementer i 


\section{Tekstlingvistikkens problemer}

de enkelte sætninger. Og man angav som eksempel på, at når dette ikke var til stede, så var der ikke kohærens og derfor heller ikke tale om en tekst. Det affødte det herostratisk berømte eksempel (også citeret i Borchmann 2010:14):

We will have guest for lunch. Calderon was a great Spanish writer (van Dijk 1972:40).

Som det ses, så betyder mangelen på referentielt sammenfald mellem de to sætninger, at teksten er usammenhængende, inkohærent. Der er ikke en samlet struktur, som gør, at teksten kan opfattes som en helhed.

Denne analyse er mødt med kritik fra flere sider (fx Polanyi 1995:45). Borchmann følger Harders kritik, som angiver, at det er læserens viden om verden, der dikterer det manglende sammenfald, men at man "faktisk kan forestille sig en kontekst hvor de to sætninger danner sammenhængende tekst" (Borchmann 2010:14). Her er konteksten, at et ægtepar har væddet en middag om, hvorvidt Calderon var digter eller opdagelsesrejsende, hvor kvinden ringer til manden og siger det ovennævnte. Andre mulige kontekster er, at et tema for en middag kunne være denne digters storhed (fra Polanyi 1995). Jeg har som andre været fascineret af den pragmatiske fantasifuldhed med henblik på at konstruere relevante kontekster og derfor som Borchmann købt dette som argument mod den tidlige kohærensanalyse fra van Dijk. Men jeg tror argumentet er forkert, og at der kan være mere sandhed i den oprindelige van Dijk-teori - trods den hårde medfart, den har haft.

Men det kræver, at vi skelner mellem tekster og meningsfuld sammenstilling af sætninger (/ytringer - skellet er ikke vigtigt i denne sammenhæng). Det vil sige, at vi ikke kun opererer med dikotomien: tekster - ikke-tekster, men tekster som meningsfuld sammenføjning af sætninger, og denne kategori er medlem af klassen af meningsfuld sammenføjning af sætninger, der er ekstentionelt større, dvs. der eksisterer medlemmer af denne kategori, som ikke er tekster. Uden for denne mængde, der har tekster som delmængde, eksisterer der så en restkategori af ikke-tekster (der evt. selv kunne have Togebys (1993) begreb om tekstoider (mislykkede tekster) som delmængde).

Calderon-eksemplet er således, ifølge denne opdeling, ikke nogen tekst. Den er ikke kohærent. Men den er meningsfuld - ikke i første omgang, men tilføjet (eller sat i) den rette kontekst. Kan man ikke finde den 


\section{Ib Ulbak}

rette kontekst, eller befinder man sig ikke i den rette kontekst, så er en tekst hverken meningsfuld eller kohærent, dvs. ikke en tekst, men blot sammenstillede sætninger.

Calderon-eksemplet kan dog godt blive til en tekst, nemlig i det øjeblik konteksten er transformeret ind i eksemplet, sådan som det sker i Borchmanns note, hvor det bliver til en lille historie. Sådan her:

Et ægtepar har væddet en frokost med nogle andre om hvorvidt Calderon var en stor spansk digter eller en portugisisk opdagelsesrejsende. Konen ringer til manden fra biblioteket og siger: 'We will have guests for lunch. Calderon was a great Spanish writer' (Borchmann 2010:36).

$\mathrm{Nu}$ er konteksten suget op i eksemplet og dermed danner det hele en kohærent helhed, en tekst. Vi ser så også, hvad der er med til at gøre teksten kohærent, der er stabile diskursreferenter: Ægtepar (mand, kone), frokost, Calderon, gentagelse af prædikationen 'stor spansk digter' (godt nok den ene gang på engelsk, så vi infererer, at det er et engelsktalende ægtepar). Der er en emneudvikling koncentreret om det samme, væddemålet. Og der gives mulighed for at inferere: at konen har tjekket oplysningerne om Calderon, at de har tabt væddemålet. Teksten har et udledbart formål, i og med man kan forstå historien og dens pointe.

Hvad er så forskellen mellem en tekst og en meningsfuld sammenstilling af sætninger? Svaret burde være indlysende på baggrund af det, jeg har skrevet ovenfor. Sammensætningen, som blot er meningsfuld, er det på baggrund af en kontekst. Den er kontekstafhængig. Den kohærente tekst er ikke blot kohærent. Den er skrevet, så den er uafhængig af en kontekst, dvs. forståelig i enhver kontekst.

$\mathrm{Nu}$ bliver det rigtig, rigtig ubehageligt - især hvis man, som jeg, er pragmatiker. Konfronteret med kontekstuafhængighed har en pragmatiker normalt et arsenal af besværgelser, som kan mane den i jorden, fx Searles dictum: 'Der findes ingen nul-kontekster' (Searle 1979). Men det vil være rigtig ærgerligt, at vi for at følge dogmet mistede en vigtig pointe angående tekster. Det er rigtigt, at alle tekster har en kontekst, så det er ikke for at afvise den del af pragmatikkens fundament, men det særlige ved tekster er måske også, at de frigør sig fra kontekster. Konteksten for Borchmann/Harders lille historie er selvfølgelig, at den 


\section{Tekstlingvistikkens problemer}

er konstrueret for at modbevise (eller i det mindste være evidens i en modargumentation mod) en præmis for tekstlingvistikken, nemlig at tekster er velformede, når de er kohærente (eller det kohærente ved tekster er med til at skabe deres velformethed). Men denne kontekst spiller ingen rolle for forståelsen af teksten, og givet teksten uden for denne kontekst ville sikkert ingen kunne pege tilbage eller rekonstruere konteksten for teksten. Jeg er selv opmærksom på, at selv hvis dette er det rette spor, så er man nødt til at relativere noget af påstanden, fordi der vil være tekster, for hvilke dette ikke stemmer.

Funktionen for konteksten for fx Calderon-eksemplet (men også for andre af Borchmanns eksempler) er at være støtte for forståelsen. Det er uforståeligt uden. På tilsvarende måde er funktionen af den opsugede kontekst i Calderon-teksten (altså den udfoldede tekst konstrueret af Harder/Borchmann) at være støtte for enten det oprindelige udsagn, eller for den måde, den sammen med andre elementer i teksten danner en pointe. Det peger i retning af det gode skel, som Togeby oprettede mellem budskabsudsagn og støtteudsagn (Togeby 2003:116f.). Som han prægnant formulerer det, så er budskabsudsagnet relevant, men uforståeligt i sig selv, mens støtteudsagnene er irrelevante, men nødvendige for forståelsen af budskabsudsagnet (se også om tekstens rundbuestruktur, Togeby 2003:124). Som en udvidelse af Togebys bestemmelser kan vi konkludere, at noget af tekstens struktur som støtteudsagn handler om oprettelse af kontekst som frigørelse fra skrivekonteksten.

Opsamlende for denne diskussion kan vi sætte den nye distinktion på formel:

1. Meningsløs sammenstillen af sætninger: uforståelig i enhver kontekst, ingen kontekst til at sikre meningsfuldhed.

2. Meningsfuld sammenstillen af sætninger: forståelig i bestemte kontekster, konteksten sikrer meningsfuldhed.

3. Tekstlig, kohærent, sammenstillen af sætninger: forståelig uafhængig af bestemte kontekster, konteksten unødvendig for at sikre meningsfuldhed.

Calderon har ikke levet forgæves, hvis han på den måde giver anledning til at præcisere, på hvilken måde kohærens er konstituerende for tekster! 


\section{Ib Ulbak}

\section{Kohæsion - hvad skal vi med det?}

Til begrebet kohæsion knytter der sig det særlige problem, at forekomsten afkohæsionsskabende elementer afHalliday opfattes som konstituerende for tekster. Borchmann peger med endnu et eksempel fra Harder på, at der eksisterer tekster, som er fuldgode kommunikationsprodukter, men som ikke har referentiel identitet på tværs af sætningsgrænserne, dvs. ikke indeholder kohæsion (Borchmann 2010:14). Så kan kohæsion ikke alligevel være tekstkonstituerende.

Denne analyse er jeg faktisk enig i. For mig er kohæsion lige præcis et "overfladefænomen", dvs. et fænomen knyttet til den sproglige realisering af et tekstligt budskab. De kohæsive elementer kan vælges til og fra afhængig af, hvordan man ønsker at gestalte sin tekst. Man kunne forledes til at tro - og muligvis er det også Borchmanns antagelse - at der er to niveauer i den tekstlingvistiske beskrivelse: kohærens/ makrostrukturer og kohæsion/mikrostrukturer. Og at med de to redegørelser er beskrivelsen udtømt. Det er korrekt, at kohæsion knytter sig til den lokale sammenbinding af sætninger, men kohæsion gør netop det: knytter sig. Kohæsion skaber ikke den lokale sammenhæng mellem sætninger (forstået som bærere af udsagn/propositioner). Kohæsion signalerer den blot. Lokal kohærens er et mere abstrakt begreb end kohæsion og kan etableres uafhængig af kohæsionen. Den systematiske analyse er derfor global kohærens versus lokal kohærens. I dette skel optræder kohæsion ikke, fordi begrebet ikke er afgørende for kohærens. Men skellet mellem global og lokal kohærens er vigtigt. Der kan være lokal kohærens uden global, hvorved tekster får et noget diffust udtryk, jf. van Dijks glimrende eksempel:

John var syg, så han ringede til lægen. Men lægen kunne ikke komme, fordi hans kone ville i teatret med ham. De spillede Othello, som hun ikke synes de kunne forpasse, for Shakespeare er en af de få dramatiske forfattere, som [...] (van Dijk, 1980:40, citeret fra Ulbæk 2005:60).

Makrostrukturanalysen ville ikke kunne gennemføres på en tekst som denne, fordi det ikke er indlysende, hvilken information man kan reducere væk, dvs. indordne under anden information, der kan angive tekstens overordnede påstand. Der er masser af lokal kohærens og også kohæsion. 


\section{Tekstlingvistikkens problemer}

Vi kan bruge Harders eksempel til at diskutere, hvordan den lokale kohærens etableres.

Du kommer til at købe ind i dag. Fredrik har forstuvet anklen og er på skadestuen. Jeg skal have en ny tandbørste. Købmanden lukker først klokken 7 (Harder 1979, citeret i Borchmann 2010:14).

Som den står, er den efter tekstlingvistikkens mening (sådan som jeg ser det) ikke nogen kohærent tekst. Her må vi så anskue den pragmatisk. Den signalerer, at den er en tekst ved at sætningerne er anbragt $i$ en lineær rækkefølge og dermed følger de tekstlige konventioner. Til forståelse heraf har jeg foreslået et ikonicitetsprincip for mening:

Betydningselementer, som er anbragt nær hinanden, har en betydningsmæssig nær relation til hinanden (Ulbæk 2005:36).

Ved læsning af Harder-teksten vil læser altså forvente dette princip overholdt og da det ikke er tilfældet, så forsøger læser at få princippet til at gælde alligevel, dvs. forsøger at inferere en sammenhæng (jf. også Borchmann 2010:26). (Jeg skal skynde mig at sige, at princippet kun gælder for så vidt Grices samarbejdsprincip gælder (Grice 1989); det er altså under den forudsætning).

Det, modtager mangler, er at etablere tekstkonnektion mellem sætningerne (jf. Togeby 1993, 2003). Forholdet mellem første og anden sætning er en begrundelsesrelation: "Du kommer til at købe ind, fordi Frederik har forstuvet ankelen og er på skadestuen”. Modtager må formodes at vide, hvilken betydning kendsgerningen om Frederik har for hvem, der kan købe ind, så vedkommende behøver ikke inferere videre. Vi andre udenforstående vil nok lave forskellige gisninger angående relationen mellem jeg, du og Frederik, og hvordan Frederiks uheld generer en afvigelse fra det normale indkøbsmønster. Det er bemærkelsesværdigt, at det er muligt med så få oplysninger, omend irrelevant her; men det peger dog i samme retning: at teksten er inferensbase for en mere udvidet tekst, hvor den lokale kohærens indfinder sig. Og det sker uden etablering af kohæsion.

Jeg gentager: Kohæsion er ikke så væsentlig for en tekstlingvistik som Halliday påstår, men uvæsentlig er den ikke. I Ulbæk (1999) rapporteres et teksteksperiment med korte tekster, som forelægges 


\section{Ib Ulbak}

forsøgspersoner. Teksterne er klippet ud i enkeltsætninger og forelægges forsøgspersonerne i en tilfældig rækkefølge. De instrueres i at lægge teksterne i den rækkefølge, som for dem giver bedst mening. Det er for så vidt et eksperiment $\mathrm{i}$ egen ret, fordi det tester forestillingen om den meget subjektive meningskonstruktion af tekster. Den helt ekstreme subjektivisme ville mene, at en hvilken som helst rækkefølge ville give subjektiv mening, altså ville der ikke være nogen prioriteret rækkefølge. Det kunne gælde for "de tomme pladser"-teorien (Iser 1981), men er vanskeligt at sige, da den ikke er særlig konkret i udpegningen af disse og ej heller, hvilke konsekvenser teorien har andet end, at læseren selv udfylder dem. Man kan også forstå teorien som ovenfor i Hardereksemplet, hvor der var en tom plads til en konneksion mellem de første to sætninger. Her er det så op til teorien at specificere, hvad en rationel agent stiller op med tekster af den type, hvor det kan gå fra en voluntaristisk type, hvor jeg selv bestemmer, hvad jeg vil udfylde uafhængig af det kommunikative formål, til en griceiansk agent, der samarbejder kommunikativt (som i andre sammenhænge). Den test bekræftede min egen hypotese om en stor indbyrdes enighed forsøgspersonerne imellem. De havde stor tendens til at konstruere samme rækkefølge af de enkelte tekster. Så der er ikke hverken hold i en subjektivistisk eller en voluntaristisk teori for tekstreception, hvis man skal tro dette forsøg.

Men forsøget havde også et andet aspekt, hvor forsøget er kontrol for en forsøgsserie, hvor der er taget kohæsive elementer ud af teksten. Pointen med forsøget er, at teksten på indholdsplanet er uforandret, men på tekstoverfladen ændres fx pro-former til fuldformer. Hypotesen er her, at den kohæsive styring af teksten løsnes og overlades mere til indholdsplanet, og at dette kan aflæses ved, at teksterne vil udvise større variation i forhold til kontrolgruppen af tekster. Dette viste sig at holde stik. Forsøgspersonerne var mere tilbøjelige til at lægge teksterne i forskellig rækkefølge (for en mere udførlige gennemgang af eksemplerne, se Ulbæk 1999 eller 2005:47ff.).

Sagen er klar. Der er grund til at kigge på både makro- og mikrostruktur, på global og lokal kohærens. I forbindelse med den sidste vil man kunne se på kohæsion som et middel til at binde teksten sammen. Men netop kun se den som et middel. 


\section{Den enthymemiske tekst}

Når mennesker kommunikerer, så sker informationsudvekslingen ud fra et kompromis mellem taler og hører. Taler ønsker at bruge mindst mulig energi på at aflevere sit budskab, men har dog en interesse $i$ at blive forstået (og fulgt, hvis det er direktivt). Hører ønsker tilsvarende at bruge mindst mulig energi på at skulle udlede og udfolde en fuldere mening end den modtagne, men kan tilsvarende have en interesse i at forstå det. Foruden hvad der er af indbyrdes social interaktion, der kan føre til udvidelse af det sagte (fx høflig indirektehed). Så for kort og for langt er begge onder, som bør undgås: Sig det nødvendige og ikke mere. $^{2}$

En måde at forkorte på er at undlade at sige det, som modtager allerede ved. Eller som Aristoteles, verdens første tekstteoretiker, sagde om den enthymemiske slutning: "Hvis [...] en af præmisserne er kendt, behøver den ikke udsiges; tilhøreren lægger den selv til" (Aristoteles 1983:38). Hvis man oven i dette lægger det, som Levinson (2000:28) betegner som en flaskehals, at vi tænker fire gange hurtige, end vi artikulerer, så er der endnu en grund til at lægge kommunikation til rette på en måde, så kodningen aflastes af inferenser: "The essential asymmetry is: inference is cheap, articulation expensive, and thus the design requirement are for a system that maximizes inference" (Levinson 2000:29).

Borchmann havde, som vi har set, eksempler på tekster, der ikke var kohærente, men dog kommunikativt funktionelle (eller kunne blive det i rette kontekst). Han har også et eksempel på en tekst, som er (til overmål) kohærent, men - til hans irritation - kommunikativt ikkefunktionel. Det er denne, skabt af et computerprogram (Talespin):

John Bear is somewhat hungry. John Bear wants to get some berries. John Bear wants to get near the blueberries. John Bear walks from cave entrance to the bush by going through a pass through a valley through a meadow. John Bear takes the blueberries. John Bear eats the blueberries. The blueberries are gone. John Bear is not very hungry (Borchmann 2010:25).

Man må være enig med Borchmann i, at teksten mangler et formål, men det er nu ikke så svært at tilføre. Man kan fx tilføje til sidst: This is how a bear spents most of his days in the summer. Men der er stadig 


\section{Ib Ulbaek}

en diskrepans mellem en ordinær kommunikerende tekst og så denne. Og det er faktisk interessant, at der er denne diskrepans. For det er jo rigtigt, at teksten er kohærent, og hvis det alene skulle være kriteriet på tekster, så fejler tekstlingvistikken af den grund. Men det kan jeg ikke se er noget problem i: at tekstlingvistikken har som sin opgave at give en redegørelse for det kohærente aspekt ved tekster og så have en mere bred redegørelse for, hvornår ytringer er vellykket kommunikation (jf. også ovenfor om forskellen på tekster og meningsfuld sammenstillen af ytringer).

Diskrepansen kan bruges til at analysere, hvad der begynder som en "fuld" tekst - forstået på den måde, at det kunne være den tænkte helhed, før tanken møder den kommunikative flaskehals, eller det kunne være den tekst, som var modtagers udfoldede tankeprodukt efter at have mødt den rigtige tekst. Dette med henblik på at skabe den kommunikerende tekst.

Hvordan skulle den rigtige tekst så se ud? Her kan man bruge indsigter fra både tekstlingvistikken og pragmatik. Og det kan bruges skrivepædagogisk, hvor man både kunne lade studerende lave teksten om i et hug og så forsøge at forklare, hvad de har gjort, eller bede dem gøre det i flere omgange, fx begyndende med kohæsion - at oprette anaforiske relationer mellem gentagede diskursreferenter:

John Bear is somewhat hungry. He wants to get some berries. He wants to get near the blueberries. The hungry bear walks from cave entrance to the bush by going through a pass through a valley through a meadow. He takes the blueberries. He eats the blueberries. They are gone. John Bear is not very hungry.

Derefter kunne man oprette konneksion mellem de enkelte sætninger:

John Bear is somewhat hungry, so he wants to get some berries. He wants to get near the blueberries, so the hungry bear walks from cave entrance to the bush by going through a pass through a valley through a meadow. He takes the blueberries and then he eats the blueberries. They are gone, so John Bear is not very hungry.

Som det ses er der mest tale om konsekvensrelationer og eksplicitering af tidsrelationer. Endelig kan vi fjerne den information, som ikke behøver at udsiges, fordi tilhøreren selv "lægger den til”" (og tilføje formålet): 


\section{Tekstlingvistikkens problemer}

John Bear is somewhat hungry, so he wants to get some berries. The hungry bear walks from cave entrance to the bush by going through a pass through a valley through a meadow. He eats the blueberries. John Bear is not very hungry. This is how a bear spents most of his days in the summer.

Jeg hævder ikke, at dette er nogen optimal tekst, men nu ligner den dog noget, vi ville kunne finde på at kommunikere. Det gode ved eksemplet er, at vi nu har set demonstreret, på hvilken måde vi kan gå fra en ikke-funktionel, men kohærent tekst, til en funktionel tekst, som trods sletninger har bevaret sin kohærens. Og at vi har brugt nogle af de metoder, som indgår i tekstlingvistikkens arsenal.

\section{Tekstlingvistik og kognition}

Ét er tekster som foreliggende som reelt objektivt tilgængelige produkter, noget andet er at se dem i en produktions- og receptionsproces, hvor indre, mentale tilstande og processer skal medtænkes. Kommer tekster fra indre tekster, fordi vi tænker i sprogligt strukturerede enheder og helheder, eller kommer de fra abstrakte og vage ideer, hvor vi først egentlig ved, hvad vi kommunikerer, når vi har formuleret vores tekst eller ytring? Tænker vi sprogligt eller i billeder? Hvad sker der, når vi skriver og læser, hvad er dynamikken i de kognitive strukturer, som understøtter disse processer? Hvordan relaterer vi den modtagne information til den information, vi allerede besidder, og hvad sker der med den modtagne information over tid, hvad huskes og hvad glemmes? Alt dette er gode og gedigne spørgsmål, som presser sig på i det øjeblik, man tænker tekster ind $\mathrm{i}$ en psykologisk ramme, når man vil forstå, hvordan tekster skabes og forstås af mennesker set kognitivt.

Et af kritikpunkterne rettet mod de to teorier, Borchmann er kritisk overfor, kohæsionsteorien og makrostrukturteorien, angår netop forholdet til det kognitive.

Kohæsionsteorien kritiseres for blot at operere med interne kæder af udtryk for samme entiteter, der kan substitueres for hinanden. Borchmann citerer kritik fra Brown \& Yule (1983:202), der med et simpelt eksempel viser, at denne teori ikke kan være sand. Refererede

entiteter kan undergå så essentielle forandringer, at tidligere udtryk ikke 


\section{Ib Ulbak}

kan substituere senere uden absurde konsekvenser. Og han anfører, at man ikke bør tænke de anaforiske relationer mellem udtryk uafhængig af personernes viden om verden. Desuden foreslås, at man relaterer udtrykkene til ikke-sproglige mentale repræsentationer, som man kan manipulere efter de forandringer, der sker med dem ned gennem teksten.

For at løse koreferensproblemet må man i stedet antage at sprogbrugere konstruerer repræsentationer $\mathrm{i}$ et ikke-sprogligt format (hvor simple disse end måtte være), og at hver sætnings indhold således ikke kobles på den foregående via semantiske relationer, men løbende omsættes til forandringer af repræsentationen (Borchmann 2010:17).

Jeg kan såmænd godt følge tankegangen og erklære mig enig, men har alligevel et par kommentarer til det foreslåede. Dels mener jeg, at der ikke kan være tale om et så forpligtende "må", som Borchmann antager. Det er rigtigt, at Johnson-Laird, som bruges i artiklen, i sin 1983-bog, Mental models, antog at mennesker ræsonnerer i mentale modeller, der har en minimal analogi med reelle entiteter, men allerede dengang blev han udsat for massiv kritik, og der var i det hele taget en større kontrovers mellem sproglige symbolister og mentale billede-teoretikere (jf. Bernsen \& Ulbæk 1993). Så det er ikke simpelt og ukontroversielt at antage, at disse mentale repræsentationer er ikke-sproglige. Og faktisk er der samtidige og nyere teorier inden for formel semantik, som i en logisk ramme forsøger at adressere de problemer, som Borchmann rejser. Jeg tænker på Hans Kamps Discourse Representation Theory, DRT (Kamp \& Reyle 1993), og Irene Heims File Change Semantics (Heim 1982) (for introduktion til begge, se Kadmon 2001). Fælles for dem er, at de inden for almindelig prædikatslogik giver mulighed for at opdatere de logiske formler, så anaforiske udtryk kan samordnes og information om diskursindivider kan føjes til. Heims teori er mest tilgængelig for en kort forklaring, fordi hun bruger et kartotekskort som metafor for et individ. På kortet noteres så de forskellige egenskaber, et individ tilskrives ned gennem en tekst. Jeg vil mene, at det er muligt at notere de tidsligt forankrede tilstande et individ undergår, såsom at en kylling overgår fra at være levende til at være ovnstegt og dermed stendød (som Brown \& Yules eksempel gik ud på). 


\section{Tekstlingvistikkens problemer}

I forhold til anaforicitet kan det komme ud på et, om individet er repræsenteret ved en simpel bogstavskonstant eller en indgang $\mathrm{i}$ et kartotekssystem, eller om man vælger en mere figurativ tilgang, som Borchmann foreslår. Det må afhænge af, hvor godt repræsentationstypen kan integreres i det øvrige kognitive maskineri. Formallogiske teorier har deres styrker og svagheder også i forhold til at være modeller af menneskelig kognition, men de har den fordel, at de både kan fungere som model for sprogligt indhold og almindelig menneskelig tænkning. Der er med andre ord en simpel forbindelse mellem det sproglige input og så visse dele af det kognitive apparat. Den simpelhed gælder ikke, når man ønsker at oversætte sprog til ikke-sproglige mentale repræsentationer.

I sin gennemgang koncentrerer Borchmann sig om van Dijks tidlige forskning, hans doktor-afhandling fra 1972 og en senere bog fra 1977 som begge opererer med tekstgrammatik. I en noget senere forskningsoversigt (og hyldest til sin samarbejdspartner gennem ti år, Walter Kintsch) skriver van Dijk selv om dette begreb: "For me, the beginning was "text grammar," a concept I now use with some hesitation, if not shame." (van Dijk 1995:384). Der sker en teoretisk udvikling væk fra den chomskyanske position, hvor dels begrebet om makrostruktur bliver udfoldet og dels, qua samarbejdet med Kintsch, sker der en integration af tekstteorien med den nye kognitionsvidenskab med henblik på at se teksten i en forståelseskontekst. Parallelt med Johnson-Laird og andre publicerer van Dijk og Kintsch Strategies of discourse comprehension (1983), hvor mentale modeller indgår:

The overall goal of text understanding [...] would no longer be, as we had assumed until the end of the 1970s, the construction of a textual representation (textbase) in episodic memory, but rather a model of the event or situation referred by the text [...] Such models would of course be subjective: It would feature personal associations, inferences, and fragments of other models (i.e., previous experiences). Hence, the model of a text would be personal, ad hoc and unique, and define one specific interpretation of one specific text at a specific moment (van Dijk 1995:394).

Som hos Borchmann vil sådanne modeller tjene tekstforståelsen:

(M)odels were also necessary to explain what most psychologists had ignored, and what was crucial in a theory of discourse: reference, co-reference, and referentially based coherence. With a 


\section{Ib Ulbak}

model, all this was easy, elegant and transparent: Texts are simply interpreted relative to a model. Argument overlap, hence, was no more than a strategic surface expression of underlying continuity of discourse referents in a model (van Dijk 1995:395).

Således har jeg svært ved at se den store teoretiske uenighed mellem Borchmann og den van Dijk, der udvikler sin teori fra en noget uholdbar forestilling om regelgenererede tekster til en, hvor der er en kompleks interaktion mellem aktuelt tekstinput og vidensstrukturer (og andet, såsom holdninger og følelser (van Dijk 1995:398).

\section{Nytten af makrostruktur og kohæsion}

Når jeg har indtænkt pointer fra kohæsionsteorien i min forskning og formidling, så har jeg ikke set den som andet end en beskrivelse af de måder, sproglige elementer knytter sig til andre på tværs af sætningsgrænsen. Jeg ser den ikke som en teori for tekster. Det er muligt, at jeg dermed gør Halliday uret; men så må det være sådan.

Anderledes forholder det sig med makrostrukturteorien. Det er i mine øjne en genuin teori for kohærens og også for menneskelig erindring i den forstand, at de reducerede tekster svarer til de referater, som mennesker giver af læste tekster (jf. van Dijk 1980). Så den indeholder en påstand om makrostrukturer som mentale realiteter. Og for så vidt teorien indeholder en transformationsproces for at gå fra den konkrete og fulde tekst til et koncentrat, som rummer erindrede informationer, så har den i det mindste det for sig, at den ikke indbefatter nogen forestilling om, at vi kan huske tekster bogstaveligt. Og det er en position, som også Borchmann finder korrekt.

Ideen om afhængighedsrelationer mellem de forskellige propositioner i tekster er tiltalende. Det er en forudsætning for at kunne lave reduktionsregler. Man kan så diskutere om reduktionsreglerne er adækvate, om de skal indlejres mere i pragmatisk formålsrettet forståelse etc. Det er op til den teoretiske udfoldning. Jeg er godt klar over, at man kan kritisere makrostrukturteorien for helt at være galt afmarcheret $i$, at den mener, at dens regler kan finde anvendelse uafhængig af teksternes kommunikative kontekst, men omvendt kan man (i det mindste hypotetisk) tjekke, om det gør en forskel, om man bruger dem abstraheret eller i en kontekst: Opstår der forskellige makrostrukturer af de to tilgange til tekstreduktionen? 


\section{Tekstlingvistikkens problemer}

I øvrigt er det ofte sådan, at smukke simple teorier render ind i problemer, når virkelighedens mere kringlede natur skal forklares. Grice giver, som bekendt, en fornem redegørelse for, hvordan vi kan kommunikere andet end det, vi siger med det, vi siger, med sit samarbejdsprincip og de fire maksimer. Men både tilhængere og modstandere af Grices teori har påpeget, at de er vage og ikke så nemme at operationalisere (jf. Levinson 1983; Sperber \& Wilson 1986; Davis 1998).

Makrostrukturteorien er dog ikke nogen fuldstændig redegørelse for kohærens i tekster. Den er et bud på, hvordan man kan forstå teksten globale kohærens. Dens gentagne applikationer af reduktionsreglerne, indtil man når til en enkelt proposition til den forventning, man har om en tekst, at den har et enkelt budskab (jf. Togeby 1993), eller det, at man kan angive en teksts emne med dens titel. Hertil kan føjes andre teorier om tekststruktur, fx min egen pipelineteori om afsnitsorganisering (Ulbæk 2003).

Grunden til, at man finder makrostrukturteorien i lærebøger, behøver således ikke bero på teoretisk slendrian, men måske nok på, at man har accepteret visse teorier og ikke andre. Der er desuden god pædagogik indbygget $\mathrm{i}$ teorien, som gør, at man kan anvende den i undervisningen og gøre studerende klar, hvordan man kan inddampe tekster i flere omgange og ende med at vurdere om fx tekstens egen overskrift modsvarer makropropositionen.

De tidligere nævnte Brown \& Yule har et credo som jeg ikke deler:

Within chunks of language which are conventionally presented as texts, the hearer/reader will make every effort to impose a coherent interpretation, i.e. to treat the language thus presented as constituting 'text'. We do not see an advantage in trying to determine constitutive formal features which a text must possess to qualify as a 'text'. Texts are what hearers and readers treat as texts (Brown \& Yule 1983:199).

Det er ikke, fordi jeg ikke kan følge dem et stykke af vejen. Men jeg har svært ved at følge dem hele vejen, så tekster blot er det, som læser/ hører opfatter som tekst, dvs. der lægges op til en relativ arbitrær opfattelse af, hvad tekster er. Hvis man jævnfører med det ovenfor 


\section{Ib Ulbak}

nævnte receptionseksperiment, som jeg gennemførte, så er der heller ikke belæg for en sådan arbitraritet. Information har det bedst med at blive præsenteret $\mathrm{i}$ en bestemt rækkefølge. Min erkendelsesinteresse her er at forstå, hvordan tekster udfører det job, ikke at pådutte teksten "formelle træk". Men hvis tekster gestaltes på en bestemt måde og ikke på andre, så kan man for mig gerne opfatte disse former som bestemte træk ved tekster, altså formelle træk (altså "formtræk"). At modtager har held til at påføre en tekst en kohærent fortolkning, skyldes jo ofte det banale træk ved teksten, at den er kohærent, eller at den med simple inferenser kan blive det.

Inden vi helt forlader makrostrukturteorien, skal jeg gøre opmærksom på, at den har inspireret mig til et løsningsforslag inden for en problemstilling om, hvordan sproghandlinger skal opfattes, når de skal gælde for tekster, eller som Borchmann formulerer det:

Skal en tekst betragtes som én sproghandling eller som en sekvens af sproghandlinger? (Borchmann 2010:25).

Og han svarer selv, at der må gælde et både-og: Teksten er én, og derfor er den en sproghandling, men man er også nødt til at kunne vurdere indgående sproghandlinger inde i teksten, derfor en sekvens af sproghandlinger (ibid.).

Men dette er et virkeligt dilemma, for hvis hver sekvens har selvstændig status i kraft af at være en sproghandling, så trues tekstens enhed, idet ytringerne, som det jo så er, netop er fuldt selvstændige. Omvendt hvis de ikke har deres værdi som sproghandling, så kan man ikke forstå deres bidrag i teksten og så forstår man heller ikke, hvordan den samlede sproghandling etableres. I Ulbæk (2009) analyseres dette dilemma, og selv om dilemmaet ikke synes at have nogen løsning, så kan man leve med det, hvis man tænker sproghandlingerne hierarkiseret, så nogle sproghandlinger dominerer andre, som domineres. På den måde kan de dominerede sproghandlinger reduceres væk og ved at gentage proceduren kan man ende op med den overordnede sproghandling for teksten. Så måden at have sin kage og spise den kunne faktisk bero på reduktionsregler a'la makrostrukturteorien. 


\section{Tekstlingvistikkens problemer}

\section{Konklusion}

Selv om dette er flot prosa, så behøver det ikke være sandt:

Hvis man funderer en sprogvidenskabelig tekstbeskrivelse på sproghandlingsteorien og kommunikationslogikken, har man samtidig afskrevet ideerne om makrostruktur og kohæsion; man kan ganske simpelt ikke bruge termerne sproghandling, illokution, samarbejdsprincippet og implikatur meningsfuldt i sammenhæng med disse ideer. The twain shall never meet! (Borchmann 2010:33).

Jeg har prøvet at vise, at især makrostrukturteorien stadig kan have en plads $i$ en pragmatisk funderet tekstlingvistik, at den ikke blot slæbes med rundt til diverse lærebøger i kraft af en historisk inerti, men at den faktisk har en rolle at spille i forståelsen af teksters interne organisering. Men det skyldes nok en anderledes opfattelse af, hvordan man kan se på tekster end Borchmanns. Jeg er villig til at abstrahere tekster ud af brugssammenhæng, mens Borchmann i langt højere grad fastholder pragmatikkens grunddogme: at sprog sker i kontekst.

\section{Noter}

1 Her ses bort fra diverse biografiske unøjagtigheder, at også Ruqaiya Hasan er medforfatter af Cohesion in English, og at Walter Kintsch er med til at udvikle makrostrukturteorien.

2 Men hvad så med dem, der bare taler og taler? vil man kunne indvende. Dér er svaret, at der nok er andre interesser på spil end informationsudveksling, når den fatiske kontakt bliver misbrugt.

\section{Litteratur}

Aristoteles (1983). Retorik. Viborg: Museum Tusculanums Forlag.

Bernsen, Niels Ole \& Ib Ulbæk (1993). Naturlig og kunstig intelligens introduktion til kognitionsforskningen. København: Nyt Nordisk Forlag.

Borchmann, Simon (2010). Tekster og sproghandlinger. Skandinaviske Sprogstudier 1, 37 sider.

Brown, Gillian \& George Yule (1983). Discourse analysis. Cambridge: Cambridge University Press.

Davis, Wayne A. (1998). Implicature. Intention, convention and principle in the failure of gricean theory. Cambridge: Cambridge University Press van Dijk, Teun (1972). Some Aspects of Textgrammars. Haag: Mouton. 


\section{Ib Ulbak}

van Dijk, Teun (1977). Text and Context. Explorations in the semantics and pragmatics of discourse. New York: Longman.

van Dijk, Teun (1995). On macrostructures, mental models, and other inventions: A brief personal history of the Kintsch - van Dijk theory. In: Charles A. Weaver, III, Suzanne Mannes \& C. Randy Fletcher (red.). Discourse comprehension. Essays in honor of Walter Kintsch. London: Routledge:383-410.

van Dijk \& Walter Kintsch (1983). Strategies of discourse comprehension. New York: Academic Press.

Grice, Paul (1989). Studies in the way of words. Cambridge, Massachusetts: Harvard University Press.

Halliday, M. A. K. og Ruqaiya Hasan (1976). Cohesion in English. London: Longman.

Harder, Peter (1979). Tekstpragmatik. En kritisk vurdering af nogle principielle og praktiske tilgange til tekstbeskrivelsen, med ansatser til et alternativ. In: John E. Andersen \& Lars Heltoft (red.). Nydanske Studier \& Almen kommunikationsteori 10-11. Sprogteori og Tekstanalyse. København: Akademisk Forlag.

Heim, Irene (1982). The semantics of definite and indefinite noun phrases. New York: Garland Publishers.

Iser, Wolfgang (1981). Tekstens appelstruktur. In: Michel Olsen \& Gunver Kelstrup (red.). Vaerk og loeser. København: Borgen: 102-131.

Johnson-Laird, Philip. N. (1983). Mental Models. Cambridge: Harvard University Press.

Kadmon, Nirit (2001). Formal pragmatics. Oxford: Blackwell Publishers.

Kamp, Uwe \& Hans Reyle (1993). From Discourse to Logic: Introduction to Model-theoretic Semantics of Natural Language, Formal Logic and Discourse Representation Theory. Dordrecht: Kluwer.

Levinson, Stephen C. (1983). Pragmatics. Cambridge: Cambridge University Press.

Polanyi, Livia (1995). The linguistic structure of discourse. Upubliceret, men tilgængeligt: http://homepage.mac.com/livia.polanyi/publications/ldm_ CSLI_1995.pdf

Searle, John (1979). Expression and meaning. Cambridge: Cambridge University Press.

Sperber, Dan \& Deidre Wilson (1986). Relevance. Oxford: Blackwell.

Togeby, Ole (1993). Praxt-pragmatisk tekstteori. Århus: Aarhus Universitets Forlag.

Togeby, Ole (2003). Fungerer denne scetning? København: Gads forlag.

Ulbæk, Ib (1999). Eksperimentel undersøgelse af tekstsammenhæng: et studie i tekstreception. In: Rita Therkelsen \& Ebbe Klitgård. Detaljen: tekstanalysen og dens grcenser. Bd. 2, Roskilde Universitetsforlag: Frederiksberg: 211229. 


\section{Tekstlingvistikkens problemer}

Ulbæk, Ib (2003). Pipelines og Pipelining: et forsøg på at forklare afsnitskohærens. NyS. Nydanske Studier og Almen Kommunikationsteori, nr. 31:54-81.

Ulbæk, Ib (2005). Sproglig tekstanalyse. Introduktion til pragmatisk tekstlingvistik. København: Academica.

Ulbæk, Ib 2009. Sproghandlinger og tekstbegrebet: Hvor er sproghandlingen i teksten. In: Rita Therkelsen \& Eva Skafte Jensen (red). Dramatikken $i$ Grammatikken. Institut for Kultur og Identitet, Roskilde Universitet: Roskilde:457-474.

Ib Ulbæk

Institut for Nordiske Studier og Sprogvidenskab

Københavns Universitet

ibu@hum.ku.dk 